\title{
Ecto-protein kinase CK2, the neglected form of CK2 (Review)
}

\author{
MATHIAS MONTENARH and CLAUDIA GÖTZ
}

\author{
Medical Biochemistry and Molecular Biology, Saarland University, D-66424 Homburg, Germany
}

Received January 26, 2018; Accepted February 12, 2018

DOI: 10.3892/br.2018.1069

\begin{abstract}
Ecto-protein kinases, including protein kinase CK2 (former name, casein kinase 2), have been the focus of research for more than 30 years. At the beginning of the ecto-kinase research their identification was performed with substrates and inhibitors whose specificity under the current knowledge was rather limited. Since all currently known ecto-kinases, including ecto-CK2, have intracellular counterparts, one has to exclude that an ecto-localization originates from intracellular counterparts after cell damage. Protein kinase CK2 is involved in cellular key processes such as cell cycle progression, inhibition of apoptosis, DNA damage repair, differentiation and many other processes. CK2 is composed of two catalytic CK $2 \alpha$ or CK2 $\alpha$ ' subunits and two non-catalytic CK2 $\beta$ subunits. Progress in the ecto-kinase and in particular ecto-CK2 studies was made with the use of transfected tagged CK2 subunits, which allowed to follow their individual transport and localization on the cell surface after transfection. Furthermore, immunofluorescence studies with antibodies against CK2 subunits as well as affinity chromatography with a binding partner of CK2 subunits have improved ecto-kinase research. The use of new and more specific inhibitors as well as of substrates, which do not cross the plasma membrane, have further improved the specificity for ecto-CK2. From the various substrates of ecto-CK2, it can be concluded that ecto-CK2 plays a role in Alzheimer disease, cell adhesion, platelet aggregation, immune response and cellular signalling. New tools and techniques, to study ecto-CK2 activity, are required to identify new substrates and thereby new functional implications for ecto-CK2.
\end{abstract}

\section{Contents}

1. Introduction

2. Protein kinase $\mathrm{CK} 2$

3. Substrates of ecto-CK2

4. Conclusion and future perspectives

Correspondence to: Professor Mathias Montenarh, Medical Biochemistry and Molecular Biology, Saarland University, Building 44, D-66424 Homburg, Germany

E-mail:m.montenarh@mx.uni-saarland.de

Key words: ecto-protein kinases, phosphorylation, extracellular substrates

\section{Introduction}

Cells need a versatile, fast mechanism to respond to changes in their environment. Such a fast response is possible by reversible phosphorylation of extracellular domains of cell surface proteins. Ecto (Greek word for outside)-phosphorylation is emerging as an important mechanism to regulate ligand interaction with their receptors, ion channels, signalling mechanisms, shedding from cell surfaces, cell-cell adhesion, immune response and proliferation and differentiation. Ecto-protein kinases are cell surface constituents of many cell types $(1,2)$.

Ecto-kinase activities are involved in synaptogenesis, synaptic plasticity and long-term potentiation (3), activation of the complement system $(4,5)$ and homeostasis $(6,7)$. Ecto-kinases are powerful regulatory enzymes for protein phosphorylation at the cell surface. They are critical for intercellular communication and transduction of external stimuli. Potential substrates for ecto-kinases are cell adhesion molecules, growth factors and their receptors, coagulation factors and ion channels. In some cases, ecto-kinases are shed from the surface of cells in a substrate-induced manner. Ecto-kinases have been identified as extracellular versions of known intracellular kinases. The pathway involved in their export out of the cell is largely unknown. They utilize extracellular ATP, which is present in blood plasma at a concentration of approximately $2 \mu \mathrm{M}$ (8). The cytosol of mammalian cells contains 5-10 mM ATP. This concentration gradient facilitates an increase in extracellular ATP concentration after cell activation or cell damage. It is well known that, the level of intracellular $\mathrm{Ca}^{2+}$ increases and ATP is released from endothelial cells into the medium when cells are activated by thrombin $(9,10)$. Another important argument for ecto-kinases may be the addition of exogenous substrates, which do not enter the cells, or the use of inhibitors of kinases, which do not penetrate into cells into the labelling medium. Moreover, working on ecto-kinases, it is always an important point to exclude leakage from dead cells.

Originally, two ecto-kinases have been described, c-AMP dependent protein kinase (11) and a cyclic nucleotide independent kinase (12-14). Paas and Fishelson (4) reported on two types of ecto-kinases, a serine/threonine kinase and a tyrosine kinase. These ecto-kinases were assumed to bind to lipid-anchored molecules, some of which were additionally shed into the medium of cultured cells. In addition, there is also evidence for ecto-kinases, which are shed into the culture medium without being previously attached to the cell surface. 
Notably, there is also evidence for the presence of ecto-phosphatase activity at least on endothelial cells, which was shown by using the membrane impermeable reagent, microcystin LR, which inhibits protein phosphatases PP-1 and PP-2a (15). Walter et al have identified protein kinases CK1 and CK2 as ecto-kinases on HeLa cells (14). Moreover, CK2-like kinases have been reported to be secreted from activated platelets, neutrophils and endothelial cells $(7,16,17)$.

\section{Protein kinase CK2}

Knowledge regarding protein kinases and in particular protein kinase CK2 has increased considerably. The human kinome consists of 518 protein kinases (18). The common feature of these protein kinases is the transfer of the terminal phosphate group of a nucleotide to a serine, threonine or tyrosine residue of substrate proteins. The majority of protein kinases employ ATP as a phosphate donor, and only a few other kinases, including CK2, can also use GTP as a phosphate donor. Most of the protein kinases are serine/threonine kinases, some are tyrosine kinases and only a few, such as CK2, are dual-specific kinases, phosphorylating serine, threonine and tyrosine (19).

The number of cell proteins, which are phosphorylated by CK2, is increasing rapidly (20) and therefore it is not surprising that CK2 is involved in almost every cell process regulating cell proliferation, cell survival (21), apoptosis (22), DNA damage and repair (23), development and differentiation (24) and the regulation of metabolism (25). CK2 is regarded as a constitutively active enzyme. With regard to the numerous substrates of CK2 and its implication in numerous basic cell processes it is, however, hard to believe that this kinase is not tightly controlled. In many organisms, CK2 is composed of two catalytic $\alpha$-subunits or two $\alpha$-subunits and two non-catalytic $\beta$-subunits forming tetramers such as $(\mathrm{CK} 2 \alpha \mathrm{CK} 2 \beta)_{2}$, $\left(\mathrm{CK} 2 \alpha^{\prime} \mathrm{CK} 2 \beta\right)_{2}$ or $\left(\mathrm{CK} 2 \alpha \mathrm{CK} 2 \alpha^{\prime}\right) /(\mathrm{CK} 2 \beta)_{2}$, which can further aggregate into multimers of this basic tetramers $(26,27)$. Since the tetramers and higher molecular weight complexes differ in their kinase activity, self-aggregation and dissociation seem to be involved in the regulation of CK2.

In addition to the tetramers and higher molecular complexes there is increasing evidence for the existence of CK2 $\alpha-, \alpha^{\prime}$ - and $\beta$-subunits aside from the CK2 tetrameric holoenzyme. There are substrates, which are phosphorylated by the holoenzyme, in addition to substrates that are phosphorylated by CK $2 \alpha$ or CK $2 \alpha^{\prime}$ alone and by the holoenzyme. Finally, there are substrates that are phosphorylated by CK2 $\alpha$, but not by the holoenzyme (28). These observations indicate a regulatory role for $\mathrm{CK} 2 \beta$, which is supported by early findings, showing that CK2 $\beta$ confers stability to the holoenzyme (29), that it determines substrate specificity (30) and it increases the enzyme activity (31). It was shown by Cochet and Chambaz that $\mathrm{CK} 2 \beta$ can enhance the catalytic activity of CK $2 \alpha$ 5- to 10-fold (32). By contrast, Meggio et al reported that CK $2 \beta$ downregulated the activity of CK $2 \alpha$ against calmodulin as a substrate (33). Polybasic compounds such as polylysine or spermidine react with an acidic cluster between residues 55 and 64 of CK2 $\beta$, thereby stimulating the kinase activity of the CK2 holoenzyme $(34,35)$. These polybasic compounds do not directly affect the CK2 $\alpha$ subunit. Recently, a new function of CK $2 \beta$ was identified by the cell-specific deletion of CK $2 \beta$ in $\mathrm{T}$ cells, which showed that CK $2 \beta$ plays an important role as a modulator of the immune response (36). There are some examples, where $\mathrm{CK} 2 \beta$ can also contribute this regulatory function to other protein kinases such as A-raf, c-mos and CHK-1 (37,38). Recently, a close interaction between CK2 $\beta$, mTOR and IGFBP-1 in hepatocellular carcinoma cells was reported (39). On the other hand, there is an increasing number of proteins binding to the CK2 holoenzyme or to CK2 $\alpha$ or $\mathrm{CK} 2 \alpha^{\prime}$ alone. These binding partners of CK2 are known to regulate CK2 kinase activity such as p53 (40-44) or PP2A and topoisomerase $(45,46)$. Thus, there are obvious cell regulators of CK2 (47-49) and vice versa, as well as other proteins that are regulated by CK2 binding (49-52).

Phosphorylation and dephosphorylation is often the main mechanism for the regulation of proteins and their activities. Cdk1 is known to phosphorylate CK2 $\alpha(53,54)$. The phosphorylation of $\mathrm{CK} 2 \beta$ by $\mathrm{CK} 2 \alpha$ as well as by cdk 1 seems to be, however, not essential for a fully active heterotetramer of CK2 (54). This led to the conclusion that phosphorylation and dephosphorylation do not play a major role in the regulation of CK2. The most important regulatory mechanism involved in CK2 seems to be its subcellular localisation. Since the beginning of research on $\mathrm{CK} 2$, it has become evident that CK2 is located in the nucleus and in the cytoplasm. However, an increasing number of studies reported that CK2 is located in almost every compartment of a eukaryotic cell. Moreover, the subcellular localisation of CK2 seems to be highly dynamic (55-58). This dynamic subcellular localisation enables the CK2 subunits to interact with proteins, which are specific for one particular cell compartment. Besides the nuclear and cytoplasmic localisation, CK2 was found at the plasma membrane $(13,59-61)$. Plasma membrane preparations from A431 cells or from insect cells expressing CK2 $\alpha$ and CK2 $\beta$ contain oligomeric forms of CK2 (62). The plasma membrane association of CK2 is mediated by a specific domain of the $\beta$-subunit (63).

In recent years, more substrates for CK2 have been identified at the plasma membrane. Since plasma membrane phosphorylation of proteins by $\mathrm{CK} 2$ were neglected thus far, the present review aims to address the role of CK2 as an ecto-kinase. An early observation identified that bone phosphoproteins were phosphorylated by CK2 isolated from detergent extracts of membranous fractions of a 12-day embryonic chick tibia (64). Although there are many early reports on ecto-CK2, little is known regarding the mechanism of how CK2 is exported to the cell surface. Tagged CK2 subunits were transfected in HEK293T cells to study their export to the cell surface. It took approximately 5-7 h after transfection before tagged subunits were detectable on the cell surface (65). When the subunits were expressed individually, they were not detectable externally. However, after transfection of both CK2 $\alpha$ and CK2 $\beta$, approximately $3-4 \%$ of the CK2 holoenzyme was detectable on the cell surface. Transport to the surface of the plasma membrane is independent of the kinase activity because a kinase-negative $\mathrm{CK} 2 \alpha$ mutant is also transported to the cell surface when CK2 $\beta$ is co-transfected. De novo protein synthesis is not required for the presence of ecto-CK2 on the cell surface (65). By using deletion and point mutants of $\mathrm{CK} 2 \beta$, the same group found that a region between amino acid 20 and 33 in the $\mathrm{N}$-terminus of CK2 $\beta$ was 
necessary for the localization of the holoenzyme on the cell surface (63). In the course of these experiments, Rodriguez et al also reported that CK2 $\beta$ can be exported out of the cells but it is not retained at the plasma membrane. A construct where the region from amino acid 20 to 33 of CK2 $\beta$ was linked to the C-terminus of CK $2 \beta$ was able to bind the CK $2 \alpha$ to form a holoenzyme, but it was unable to transport the holoenzyme to the ecto-kinase location. These results suggest that the region between amino acid 20 and 33 of CK2 $\beta$ is necessary but not sufficient for the extracellular localization of CK2 (63). Free CK2 $\beta$ interacts with several other protein kinases such as A-raf, c-mos and CHK-1 (66). One might speculate that these kinases are also transported to the plasma membrane by their interaction with $\mathrm{CK} 2 \beta$. In contrast to an early observation by Kübler et al (12), the kinase activity on the cell surface is rapidly restored (13). Ecto-CK2 is not released from the cell surface by incubation with phospholipase $\mathrm{C}$, suggesting that ecto-CK2 is not anchored in the plasma membrane via glycosyl-phosphatidyl-inositol-linkage.

Since CK2 is known to be elevated in many cancer cells and the observation that an inhibition of CK2 kinase activity leads to apoptosis of at least cancer cells $(67,68)$, there has been a search to identify new efficient and specific inhibitors of CK2 worldwide. Most of the currently known CK2 inhibitors are ATP competitors. Recently, bifunctional inhibitors have been designed, which, on the one hand bind ATP competitively, and on the other hand, mimic phospho-acceptor substrates (69-71). On the basis of 4,5,6,7-tetrabromo-1H-benzimidazol (TBI), new derivatives were generated, which compete with the phospho-acceptor sites of substrates. These bifunctional inhibitors of CK2 have impaired cell permeability, which qualifies them for the inhibition of ecto-CK2 (70).

\section{Substrates of ecto-CK2}

Table I lists the substrates, which are shown to be phosphorylated by ecto-CK2. The $\beta$-amyloid precursor protein ( $\beta$ APP) is phosphorylated within its ecto-domain and CK2 was identified as one of the ecto-kinases that phosphorylates $\beta \mathrm{APP}$ at the outer face of the plasma membrane (72). Cell surface labelling of $\beta$ APP was analysed by adding radiolabelled $\gamma$ ATP or $\gamma$ GTP to the supernatant of HEK293T cells overexpressing $\beta A P P 1-695$. The ecto-kinase activity was inhibited by heparin and by DRB, two compounds that are known to inhibit CK2 kinase activity $(73,74)$. Further experiments revealed that, not only membrane-bound $\beta$ APP, but also secreted $\beta$ APP from cell membranes, was phosphorylated by ecto-CK2.

Already in 1993, a CK2-like activity was described in thrombin-activated platelets and in the supernatant of these activated platelets. It is known that thrombin triggers at least in endothelial cells, the release of intracellular ATP (10). The presence of elevated extracellular ATP concentration and the presence of ecto-CK2 are an ideal combination for the phosphorylation of cell surface proteins.

Ecto-CK2 phosphorylated bovine coagulation factor $\mathrm{Va}$ and human factor VIII (6). Phosphorylated factor Va was more sensitive for active protein $\mathrm{C}$ than the non-phosphorylated form, triggering its degradation. This result indicates that ecto-CK2 may play a role in the downregulation of coagulation. Recently, an interesting result was reported for
Table I. Substrates for ecto-CK2.

\begin{tabular}{lc}
\hline Substrates & Refs. \\
\hline$\beta$-amyloid precursor protein & $(72)$ \\
Human factor VIII & $(6)$ \\
Coagulation factor Va & $(6)$ \\
Complement factor C3 & $(5)$ \\
Complement factor C9 & $(4)$ \\
Casein & $(17)$ \\
Fibrinogen & $(17,76)$ \\
Fibrin & $(76)$ \\
Phosvitin & $(59)$ \\
Vitronectin & $(82)$ \\
Laminin-1 & $(85)$ \\
Collagen XVII & $(87)$ \\
Osteopontin & $(88)$ \\
Stanniocalcin-2 & $(89)$ \\
Nucleolin & $(90)$ \\
\hline
\end{tabular}

megakaryocytes and platelets from $\mathrm{CK} 2 \beta^{-/-}$mice. Münzer et al showed an abnormal microtubule structure and a significantly increased fragmentation within the bone marrow (75). Aggregation of $\mathrm{CK} 2 \beta^{-/-}$platelets was abrogated and thrombus formation was reduced. Whether this effect is due to an impaired localization of CK2 on the cell surface remains to be elucidated. Another protein that is phosphorylated by CK2 is C3 (5). Phosphorylated fragments derived from C3 cleavage show an increased binding to $\mathrm{IgG}$ in serum over that of non-phosphorylated C3. Since CK2 phosphorylation of C3 increases its susceptibility to elastase cleavage, these results suggest an effect of platelet-derived CK2 phosphorylation of C3 to enhance the opsonisation of immune complexes (5).

Rat liver endothelial cells, which were activated with thrombin release up to $10 \%$ of the total protein kinase activity into the culture medium. This protein kinase phosphorylates casein and fibrinogen and the enzyme is inhibited by heparin. These features suggest ecto-CK2 (17). There was a very similar observation, i.e., cultivated hamster and chicken cells have ecto-CK2, which phosphorylates human and bovine fibrinogen as well as fibrin (76).

The C9 protein, which is a component of the lytic activity of the complement system was found to be phosphorylated by an ecto-kinase (4), which was subsequently identified as CK2 (77). In this case, the ecto-kinase activity was determined with intact cells and purified C9 protein, ATP and $\mathrm{Mg}^{2+}$. The ecto-kinase is neither influenced by $\mathrm{Ca}^{2+}$ nor by cAMP. The ecto-kinase is shed from the plasma membrane and this shed protein kinase also phosphorylates C9 protein (77). C9 phosphorylation was achieved on intact Raji cells and also by shed proteins from the surface of Raji cells. Ecto-CK2 was identified by immunofluorescence flow cytometry. Kinase activity was inhibited by emodin, TBB and DRB, which are known inhibitors of CK2 $(74,78,79)$. The three inhibitors did not reduce cell viability. In addition, CK $2 \alpha$ and CK $2 \beta$ were detected in the supernatant of K562 and Raji cells using CK2 subunit-specific antibodies. C9 is a 
blood plasma protein that binds to the C5b-8 complex of the complement system (80). C9 phosphorylation by ecto-CK2 is a protective mechanism against complement-mediated lysis (81). Phosphorylated C9 has a reduced haemolytic activity whereas the inhibition of ecto-CK2 kinase activity enhanced cell killing. In addition, C9 ecto-CK2 phosphorylated calmodulin and a highly CK2-specific peptide substrate. The level of ecto-CK2 on peripheral blood mononuclear cells (PBMC) and B cells was lower than that on Raji and K562 cells (81).

Other examples of substrates for ecto-CK2 are phosvitin and vitronectin. Vitronectin is a glycoprotein, which is present in blood and in the extracelluar matrix. At least for vitronectin, it is known that its phosphorylation is inhibited by DRB. Phosphorylation of vitronectin by ecto-CK2 regulates the adhesion of cells to the extracellular matrix (82-84). Both substrates induced the release of ecto-CK2 when vascular smooth muscle cells (VSMC) were incubated with phosvitin or vitronectin (82). When the cells were adhered to vitronectin, ecto-CK2 was enriched in clusters on the cell surface and then underwent a displacement from the VSMC surface (82).

Ecto-CK2 regulates monocyte migration through laminin-1 phosphorylation (85). Ecto-kinase activity was inhibited by heparin and CK2 was identified with CK2-specific antibodies. An interesting feature of phosphorylated laminin-1 is its interaction with heparin, where phosphorylated laminin-1 binds better to heparin than non-phosphorylated laminin-1. In cell adhesion experiments, a significantly higher amount of cells adhere to phosphorylated laminin-1 (85). Furthermore, phosphorylated laminin-1 promotes cell proliferation as well as monocyte migration.

Ecto-CK2 was also detected on mast cells RBL-2113 by its capacity to phosphorylate a CK2-specific peptide, the use of $\left[{ }^{32} \mathrm{P}\right] \gamma$ ATP as well as $\left[{ }^{32} \mathrm{P}\right] \gamma$ GTP, by western blot analysis and immunofluorescence with CK2-specific antibodies (86). CK2 was co-immunoprecipitated with an anti Fc-R antibody, indicating that ecto-CK2 is tightly bound to a receptor molecule.

Collagen XVII is an example of an integral membrane protein with an extracellular domain, which was phosphorylated by ecto-CK2 at serine 542 and 544. Collagen XVII seems to be an interesting example for hierarchical phosphorylation, because serine 544 is the first phosphorylation event, which generates an acidic environment, which then allows the serine 542 phosphorylation by CK2.

The pharmacological inhibition of CK2 with 4,5,6,7-tetrabromobenzimidazol (TBB) as well as the use of a non-phosphorylatable alanine mutant revealed that CK2 phosphorylation of collagen XVII regulates ecto-domain shedding. By contrast, the overexpression of CK2 $\alpha$ inhibited the cleavage of collagen XVII (87). An antibody against a phospho-peptide derived from a collagen XVII sequence from amino acid 535 to 551 detected CK2-phosphorylated collagen XVII on the cell surface. As a control for the specificity, a dominant negative mutant of CK2 was expressed and shown to be present on the cell surface. This mutant ecto-CK2 failed to phosphorylate collagen XVII (87). CK2 phosphorylation of collagen XVII inhibits its degradation by metalloproteases (87). The authors of that study suggested that ecto-CK2 phosphorylation is a novel mechanism involved in the regulation of adhesion and motility of epithelial cells (87).
Ecto-CK2 seems to be involved in ossification by direct influencing mineral formation through the phosphorylation of osteopontin (88). This observation is in agreement with the detection of stanniocalcin-2 (STC-2), a substrate of ecto-CK2 (89). STC-2 is a proteohormone, which is involved in the regulation of calcium and phosphate homeostasis (89).

Using affinity chromatography on urokinase-conjugated Sepharose4B and nano-electrospray mass spectrometry and by immunoblotting, ecto-CK2 was found in a complex with urokinase and with nucleolin (90), and this complex seems to be highly dynamic on the cell surface. Ecto-CK2 phosphorylated the cell membrane-associated protein nucleolin. Nucleolin is a phosphoprotein, which shuttles between the nucleus and cytoplasm and which is located on the cell surface (91). Urokinase activates ecto-CK2, leading to the phosphorylation of nucleolin and this phosphorylation is responsible for the translocation of nucleolin into the cell nucleus (90). By contrast, intracellular CK2 is insensitive in the activation by urokinase. Another example of a complex of ecto-CK2 with cell surface proteins was mentioned earlier, that of the association with Fc-R on monocytes (86).

\section{Conclusion and future perspectives}

There is a long history of a subclass of CK2 as an ecto-kinase. CK2 was identified by using casein as a substrate and with heparin as an inhibitor. It is now clear that casein is not a natural substrate of CK2. The kinase committed to the phosphorylation of casein in the Golgi apparatus of the lactating mammary gland is conventionally termed genuine or Golgi casein kinase (92).

Heparin, which was used as an inhibitor of CK2, interacts non-specifically with proteins such as cytokines, growth factors, adhesion molecules and proteases (93). DRB, not only inhibits CK2, but also RNA polymerase II (94). Thus, in both cases off-target effects cannot be excluded. The direct identification of CK2 subunits on the cell surface by immunofluorescence or by immunoprecipitation were steps forward in the identification and characterisation of ecto-CK2. Furthermore, the development of new, highly specific, cell impermeable inhibitors of CK2 and phosphorylation experiments with substrates that cannot penetrate into cells have improved the specificity for ecto-CK2. Transfection of the tagged subunits of CK2 has shown that only the holoenzyme and/or the CK2 $\beta$ subunit are present on the cell surface. It remains an open question whether there are also high molecular aggregates of the CK2 holoenzyme on the cell surface. Since CK2 $\beta$ binds also to other protein kinases and since it is responsible for the cell surface localization of CK2, it remains to be determined whether these other protein kinases are also present as ecto-kinases.

The proteins already identified earlier as substrates for ecto-CK2 show that ecto-CK2 plays a role in blood homeostasis, in thrombosis, in cell adhesion, in Alzheimer disease, calcium homeostasis and in the regulation of the immune system. Other plasma membrane-associated proteins such as ion channels and receptors for hormones and growth factors, are excellent candidates for ecto-CK2.

\section{Acknowledgements}

Not applicable. 


\section{Funding}

This study was supported by the Dr Rolf M. Schwiete Stiftung, Mannheim, Germany (project no. 06/2015) to CG and MM.

\section{Availability of data and materials}

Not applicable.

\section{Authors' contributions}

MM and CG wrote the paper.

\section{Ethics approval and consent to participate}

Not applicable.

\section{Consent for publication}

Not applicable.

\section{Competing interests}

The authors declare that they have no competing interests.

\section{References}

1. Ehrlich YH, Davis TB, Bock E, Kornecki E and Lenox RH: Ecto protein kinase activity on the external surface of neural cells. Nature 320: 67- 70, 1986.

2. Kübler D and Barnekow A: Ecto kinase activities in normal and transformed cells. Eur J Cell Biol 40: 58-63, 1986.

3. Chen W, Wieraszko A, Hogan MV, Yang HA, Kornecki E and Ehrlich YH: Surface protein phosphorylation by ecto-protein kinase is required for the maintenance of hippocampal long-term potentiation. Proc Natl Acad Sci USA 93: 8688-8693, 1996.

4. Paas Y and Fishelson Z: Shedding of tyrosine and serine/threonine ecto-protein kinases from human leukemic cells. Arch Biochem Biophys 316: 780-788, 1995.

5. Ekdahl KN and Nilsson B: Alterations in C3 activation and binding caused by phosphorylation by a casein kinase released from activated human platelets. J Immunol 162: 7426-7433, 1999.

6. Kalafatis M, Rand MD, Jenny RJ, Ehrlich YH and Mann KG: Phosphorylation of factor Va and factor VIIIa by activated platelets. Blood 81: 704-719, 1993.

7. Rand MD, Kalafatis M and Mann KG: Platelet coagulation factor Va: The major secretory platelet phosphoprotein. Blood 83 2180-2190, 1994

8. Martin SC: Phosphorylation of complement factor C3 in vivo. Biochem J 261: 1051-1054, 1989.

9. Hamilton KK and Sims PJ: Changes in cytosolic $\mathrm{Ca} 2+$ associated with von Willebrand factor release in human endothelial cells exposed to histamine. Study of microcarrier cell monolayers using the fluorescent probe indo-1. J Clin Invest 79: 600-608, 1987.

10. Gödecke S, Roderigo C, Rose CR, Rauch BH, Gödecke A and Schrader J: Thrombin-induced ATP release from human umbilical vein endothelial cells. Am J Physiol Cell Physiol 302: C915-C923, 2012.

11. Kübler D, Pyerin W, Bill O, Hotz A, Sonka J and Kinzel V: Evidence for ecto-protein kinase activity that phosphorylates Kemptide in a cyclic AMP-dependent mode. J Biol Chem 264 14549-14555, 1989.

12. Kübler D, Pyerin W, Burow E and Kinzel V: Substrate-effected release of surface-located protein kinase from intact cells. Proc Natl Acad Sci USA 80: 4021-4025, 1983.

13. Skubitz KM, Ehresmann DD and Ducker TP: Characterization of human neutrophil ecto-protein kinase activity released by kinase substrates. J Immunol 147: 638-650, 1991

14. Walter J, Schnölzer M, Pyerin W, Kinzel V and Kübler D: Induced release of cell surface protein kinase yields CK1- and CK2-like enzymes in tandem. J Biol Chem 271: 111-119, 1996.
15. Al-Nedawi KN, Pawłowska Z and Cierniewski CS: Interferon gamma bound to endothelial cells is phosphorylated by ecto-protein kinases. Acta Biochim Pol 46: 693-702, 1999.

16. Hartmann M and Schrader J: Exo-protein kinase release from intact cultured aortic endothelial cells. Biochim Biophys Acta 1136: 189-195, 1992.

17. Eriksson S, Alston-Smith J and Ekman P: Endothelial cells release casein kinase II - like activity capable of phosphorylating fibrinogen in response to thrombin. Thromb Res 72: 315-320, 1993.

18. Manning G, Whyte DB, Martinez R, Hunter T and Sudarsanam S: The protein kinase complement of the human genome. Science 298: 1912-1934, 2002.

19. Litchfield DW: Protein kinase CK2: Structure, regulation and role in cellular decisions of life and death. Biochem J 369: 1-15, 2003.

20. Meggio F and Pinna LA: One-thousand-and-one substrates of protein kinase CK2? FASEB J 17: 349-368, 2003.

21. St-Denis NA and Litchfield DW: Protein kinase CK2 in health and disease: From birth to death: the role of protein kinase CK2 in the regulation of cell proliferation and survival. Cell Mol Life Sci 66: 1817-1829, 2009.

22. Ahmad KA, Wang G, Unger G, Slaton J and Ahmed K: Protein kinase CK2 - a key suppressor of apoptosis. Adv Enzyme Regul 48: 179-187, 2008.

23. Montenarh M: Protein kinase CK2 in DNA damage and repair. Transl Cancer Res 5: 49-63, 2016.

24. Götz C and Montenarh M: Protein kinase CK2 in development and differentiation. Biomed Rep 6: 127-133, 2017.

25. Al Quobaili F and Montenarh M: CK2 and the regulation of the carbohydrate metabolism. Metabolism 61: 1512-1517, 2012.

26. Lolli G, Naressi D, Sarno S and Battistutta R: Characterization of the oligomeric states of the CK $2 \alpha 2 \beta 2$ holoenzyme in solution. Biochem J 474: 2405-2416, 2017.

27. Filhol O, Martiel JL and Cochet C: Protein kinase CK2: A new view of an old molecular complex. EMBO Rep 5: 351-355, 2004.

28. Pinna LA: The raison d'être of constitutively active protein kinases: The lesson of CK2. Acc Chem Res 36: 378-384, 2003.

29. Meggio F, Boldyreff B, Marin O, Pinna LA and Issinger OG: Role of the beta subunit of casein kinase- 2 on the stability and specificity of the recombinant reconstituted holoenzyme. Eur J Biochem 204: 293-297, 1992

30. Bidwai AP, Hanna DE and Glover CV: Purification and characterization of casein kinase II (CKII) from delta cka1 delta cka2 Saccharomyces cerevisiae rescued by Drosophila CKII subunits. The free catalytic subunit of casein kinase II is not toxic in vivo. J Biol Chem 267: 18790-18796, 1992.

31. Grankowski N, Boldyreff B and Issinger OG: Isolation and characterization of recombinant human casein kinase II subunits alpha and beta from bacteria. Eur J Biochem 198: 25-30, 1991.

32. Cochet $\mathrm{C}$ and Chambaz EM: Oligomeric structure and catalytic activity of $\mathrm{G}$ type casein kinase. Isolation of the two subunits and renaturation experiments. J Biol Chem 258: 1403-1406, 1983.

33. Meggio F, Boldyreff B, Marin O, Marchiori F, Perich JW, Issinger OG and Pinna LA: The effect of polylysine on casein-kinase-2 activity is influenced by both the structure of the protein/peptide substrates and the subunit composition of the enzyme. Eur J Biochem 205: 939-945, 1992.

34. Boldyreff B, Meggio F, Pinna LA and Issinger OG: Reconstitution of normal and hyperactivated forms of casein kinase-2 by variably mutated beta-subunits. Biochemistry 32: 12672-12677, 1993.

35. Filhol O, Cochet C, Delagoutte T and Chambaz EM: Polyamine binding activity of casein kinase II. Biochem Biophys Res Commun 180: 945-952, 1991.

36. Ulges A, Klein M, Reuter S, Gerlitzki B, Hoffmann M, Grebe N, Staudt V, Stergiou N, Bohn T, Brühl TJ, et al: Protein kinase CK2 enables regulatory $\mathrm{T}$ cells to suppress excessive $\mathrm{TH} 2$ responses in vivo. Nat Immunol 16: 267-275, 2015.

37. Bolanos-Garcia VM, Fernandez-Recio J, Allende JE and Blundell TL: Identifying interaction motifs in CK2beta - a ubiquitous kinase regulatory subunit. Trends Biochem Sci 31: 654-661, 2006

38. Boldyreff B and Issinger OG: A-Raf kinase is a new interacting partner of protein kinase CK2 $\beta$ subunit. FEBS Lett 403: 197-199, 1997.

39. Singal SS, Nygard K, Dhruv MR, Biggar K, Shehab MA, Li SS, Jansson T and Gupta MB: Co-Localization of Insulin-Like Growth Factor Binding Protein-1, Casein Kinase-2 $\beta$, and Mechanistic Target of Rapamycin in Human Hepatocellular Carcinoma Cells as Demonstrated by Dual Immunofluorescence and in Situ Proximity Ligation Assay. Am J Pathol 188: 111-124, 2018. 
40. Kraiss S, Barnekow A and Montenarh M: Protein kinase activity associated with immunopurified p53 protein. Oncogene 5: 845-855, 1990.

41. Wagner P, Appel K, Issinger O and Montenarh M: On the interaction of p53 with casein kinase-ii. Int J Oncol 4: 491-498, 1994

42. Schuster N and Montenarh M: The role of protein kinase CK2 in p53 mediated growth arrest in mouse fibroblasts. Eur J Cell Biol 72: 71-71, 1997.

43. Schuster N, Götz C, Faust M, Schneider E, Prowald A Jungbluth A and Montenarh M: Wild-type p53 inhibits protein kinase CK2 activity. J Cell Biochem 81: 172-183, 2001.

44. Cox ML and Meek DW: Phosphorylation of serine 392 in p53 is a common and integral event during p53 induction by diverse stimuli. Cell Signal 22: 564-571, 2010.

45. Hériché JK, Lebrin F, Rabilloud T, Leroy D, Chambaz EM and Goldberg Y: Regulation of protein phosphatase 2A by direct interaction with casein kinase 2alpha. Science 276: 952-955, 1997.

46. Redwood C, Davies SL, Wells NJ, Fry AM and Hickson ID: Casein kinase II stabilizes the activity of human topoisomerase IIalpha in a phosphorylation-independent manner. J Biol Chem 273: 3635-3642, 1998.

47. Llorens F, Roher N, Miró FA, Sarno S, Ruiz FX, Meggio F, Plana M, Pinna LA and Itarte E: Eukaryotic translation-initiation factor eIF2 $\beta$ binds to protein kinase CK2: Effects on CK $2 \alpha$ activity. Biochem J 375: 623-631, 2003

48. Ruzzene M, Brunati AM, Sarno S, Donella-Deana A and Pinna LA: Hematopoietic lineage cell specific protein 1 associates with and down-regulates protein kinase CK2. FEBS Lett 461: 32-36, 1999.

49. Montenarh M: Cellular regulators of protein kinase CK2. Cell Tissue Res 342: 139-146, 2010.

50. Guerra B, Issinger OG and Wang JYJ: Modulation of human checkpoint kinase Chk1 by the regulatory $\beta$-subunit of protein kinase CK2. Oncogene 22: 4933-4942, 2003.

51. Kreutzer J and Guerra B: The regulatory beta-subunit of protein kinase CK2 accelerates the degradation of CDC25A phosphatase through the checkpoint kinase Chk1. Int J Oncol 31: 1251-1259, 2007.

52. Olsen BB, Kreutzer JN, Watanabe N, Holm T and Guerra B Mapping of the interaction sites between Weel kinase and the regulatory beta-subunit of protein kinase CK2. Int J Oncol 36: $1175-1182,2010$.

53. Meggio F, Boldyreff B, Marin O, Issinger OG and Pinna LA: Phosphorylation and activation of protein kinase CK2 by p34cdc2 are independent events. Eur J Biochem 230: 1025-1031, 1995.

54. Meggio F, Boldyreff B, Issinger OG and Pinna LA: The autophosphorylation and $\mathrm{p} 34 \mathrm{cdc} 2$ phosphorylation sites of casein kinase-2 beta-subunit are not essential for reconstituting the fully-active heterotetrameric holoenzyme. Biochim Biophys Acta 1164: 223-225, 1993.

55. Filhol O, Nueda A, Martel V, Gerber-Scokaert D, Benitez MJ, Souchier C, Saoudi Y and Cochet C: Live-cell fluorescence imaging reveals the dynamics of protein kinase CK2 individual subunits. Mol Cell Biol 23: 975-987, 2003.

56. Ahmed K and Tawfic S: Mechanism of intracellular regulation of protein kinase CK2: Role of stimulus-mediated subnuclear association. Cell Mol Biol Res 40: 539-545, 1994.

57. Wang H, Yu S, Davis AT and Ahmed K: Cell cycle dependent regulation of protein kinase $\mathrm{CK} 2$ signaling to the nuclear matrix. J Cell Biochem 88: 812-822, 2003

58. Yu S, Davis AT, Guo C, Green JE and Ahmed K: Differential targeting of protein kinase CK2 to the nuclear matrix upon transient overexpression of its subunits. J Cell Biochem 74: 127-134, 1999.

59. Pyerin W, Burow E, Michaely K, Kübler D and Kinzel V: Catalytic and molecular properties of highly purified phosvitin/casein kinase type II from human epithelial cells in culture (HeLa) and relation to ecto protein kinase. Biol Chem Hoppe Seyler 368: 215-227, 1987.

60. Sargiacomo M, Scherer PE, Tang ZL, Casanova JE and Lisanti MP: In vitro phosphorylation of caveolin-rich membrane domains: Identification of an associated serine kinase activity as a casein kinase II-like enzyme. Oncogene 9: 2589-2595, 1994.

61. Wei $\mathrm{T}$ and Tao M: Human erythrocyte casein kinase II Characterization and phosphorylation of membrane cytoskeletal proteins. Arch Biochem Biophys 307: 206-216, 1993.

62. Sarrouilhe D, Filhol O, Leroy D, Bonello G, Baudry M, Chambaz EM and Cochet C: The tight association of protein kinase CK2 with plasma membranes is mediated by a specific domain of its regulatory $\beta$-subunit. Biochim Biophys Acta 1403: 199-210, 1998.
63. Rodriguez FA, Contreras C, Bolanos-Garcia V and Allende JE: Protein kinase CK2 as an ectokinase: The role of the regulatory CK2beta subunit. Proc Natl Acad Sci USA 105: 5693-5698, 2008

64. Mikuni-Takagaki Y and Glimcher MJ: Post-translational processing of chicken bone phosphoproteins. Identification of bone (phospho)protein kinase. Biochem J 268: 593-597, 1990.

65. Rodríguez F, Allende CC and Allende JE: Protein kinase casein kinase 2 holoenzyme produced ectopically in human cells can be exported to the external side of the cellular membrane. Proc Natl Acad Sci USA 102: 4718-4723, 2005.

66. Kusk M, Ahmed R, Thomsen B, Bendixen C, Issinger OG and Boldyreff B: Interactions of protein kinase CK $2 \beta$ subunit within the holoenzyme and with other proteins. Mol Cell Biochem 191: $51-58,1999$.

67. Guerra B and Issinger OG: CK2: A global regulator of cell survival. In: Protein kinase CK2. Pinna LA (ed). John Wiley \& Sons, Inc., Ames, Chichester, Oxford, pp239 266, 2013.

68. Sarno S and Pinna LA: Protein kinase CK2 as a druggable target. Mol Biosyst 4: 889-894, 2008.

69. Rahnel H, Viht K, Lavogina D, Mazina O, Haljasorg T, Enkvist E and Uri A: A Selective Biligand Inhibitor of CK2 Increases Caspase-3 Activity in Cancer Cells and Inhibits Platelet Aggregation. ChemMedChem 12: 1723-1736, 2017.

70. Cozza G, Zanin S, Sarno S, Costa E, Girardi C, Ribaudo G, Salvi M, Zagotto G, Ruzzene M and Pinna LA: Design, validation and efficacy of bisubstrate inhibitors specifically affecting ecto-CK2 kinase activity. Biochem J 471: 415-430, 2015.

71. Lavogina D, Enkvist E and Uri A: Bisubstrate inhibitors of protein kinases: From principle to practical applications. ChemMedChem 5: 23-34,2010.

72. Walter J, Schindzielorz A, Hartung B and Haass C: Phosphorylation of the beta-amyloid precursor protein at the cell surface by ectocasein kinases 1 and 2. J Biol Chem 275: 23523-23529, 2000.

73. Hathaway GM, Lubben TH and Traugh JA: Inhibition of casein kinase II by heparin. J Biol Chem 255: 8038-8041, 1980.

74. Meggio F, Shugar D and Pinna LA: Ribofuranosyl-benzimidazole derivatives as inhibitors of casein kinase-2 and casein kinase-1. Eur J Biochem 187: 89-94, 1990.

75. Münzer P, Walker-Allgaier B, Geue S, Langhauser F, Geuss E, Stegner D, Aurbach K, Semeniak D, Chatterjee M, Gonzalez Menendez I, et al: CK2 $\beta$ regulates thrombopoiesis and $\mathrm{Ca} 2+$-triggered platelet activation in arterial thrombosis. Blood 130: 2774-2785, 2017.

76. Sonka J, Kübler D and Kinzel V: Phosphorylation by cell surface protein kinase of bovine and human fibrinogen and fibrin. Biochim Biophys Acta 997: 268-277, 1989.

77. Paas Y, Bohana-Kashtan O and Fishelson Z: Phosphorylation of the complement component, C9, by an ecto-protein kinase of human leukemic cells. Immunopharmacology 42: 175-185, 1999.

78. Yim H, Lee YH, Lee CH and Lee SK: Emodin, an anthraquinone derivative isolated from the rhizomes of Rheum palmatum, selectively inhibits the activity of casein kinase II as a competitive inhibitor. Planta Med 65: 9-13, 1999.

79. Ruzzene M, Penzo D and Pinna LA: Protein kinase CK2 inhibitor 4,5,6,7-tetrabromobenzotriazole (TBB) induces apoptosis and caspase-dependent degradation of haematopoietic lineage cell-specific protein 1 (HS1) in Jurkat cells. Biochem J 364: 41-47, 2002.

80. Müller-Eberhard HJ: The membrane attack complex of complement. Annu Rev Immunol 4: 503-528, 1986.

81. Bohana-Kashtan O, Pinna LA and Fishelson Z: Extracellular phosphorylation of $\mathrm{C} 9$ by protein kinase $\mathrm{CK} 2$ regulates complement-mediated lysis. Eur J Immunol 35: 1939-1948, 2005.

82. Stepanova V, Jerke U, Sagach V, Lindschau C, Dietz R, Haller H and Dumler I: Urokinase-dependent human vascular smooth muscle cell adhesion requires selective vitronectin phosphorylation by ectoprotein kinase CK2. J Biol Chem 277: 10265-10272, 2002.

83. Seger D, Seger R and Shaltiel S: The CK2 phosphorylation of vitronectin. Promotion of cell adhesion via the $\alpha(\mathrm{v}) \beta 3$ 3-phosphatidylinositol 3-kinase pathway. J Biol Chem 276: 16998-17006, 2001.

84. Seger D, Gechtman Z and Shaltiel S: Phosphorylation of vitronectin by casein kinase II. Identification of the sites and their promotion of cell adhesion and spreading. J Biol Chem 273: 24805-24813, 1998.

85. Trachana V, Christophorides E, Kouzi-Koliakos K and Koliakos G: Laminin-1 is phosphorylated by ecto-protein kinases of monocytes. Int J Biochem Cell Biol 37: 478-492, 2005. 
86. Teshima R, Onose J, Saito Y, Ikebuchi H, Kitani S and Sawada J: Casein kinase II-like ectokinase activity on RBL-2H3 cells. Immunol Lett 68: 369-374, 1999.

87. Zimina EP, Fritsch A, Schermer B, Bakulina AY, Bashkurov M, Benzing T and Bruckner-Tuderman L: Extracellular phosphorylation of collagen XVII by ecto-casein kinase 2 inhibits ectodomain shedding. J Biol Chem 282: 22737-22746, 2007.

88. Zhu X, Luo C, Ferrier JM and Sodek J: Evidence of ectokinase-mediated phosphorylation of osteopontin and bone sialoprotein by osteoblasts during bone formation in vitro. Biochem J 323: 637-643, 1997.

89. Jellinek DA, Chang AC, Larsen MR, Wang X, Robinson PJ and Reddel RR: Stanniocalcin 1 and 2 are secreted as phosphoproteins from human fibrosarcoma cells. Biochem J 350: 453-461, 2000.

90. Dumler I, Stepanova V, Jerke U, Mayboroda OA, Vogel F, Bouvet P, Tkachuk V, Haller H and Gulba DC: Urokinase-induced mitogenesis is mediated by casein kinase 2 and nucleolin. Curr Biol 9: 1468-1476, 1999.
91. Ginisty H, Sicard H, Roger B and Bouvet P: Structure and functions of nucleolin. J Cell Sci 112: 761-772, 1999.

92. Venerando A, Cesaro L and Pinna LA: From phosphoproteins to phosphoproteomes: A historical account. FEBS J 284: 1936-1951, 2017.

93. Aláez-Versón CR, Lantero E and Fernàndez-Busquets X: Heparin: New life for an old drug. Nanomedicine (Lond) 12: 1727-1744, 2017.

94. Clement JQ and Wilkinson MF: Rapid induction of nuclear transcripts and inhibition of intron decay in response to the polymerase II inhibitor DRB. J MolBiol 299: 1179-1191, 2000. 